Article

\title{
Platinum and rhodium in potatoes samples by using voltammetric techniques
}

\author{
Diana Amorello, Santino Orecchio \\ Dipartimento di Scienze e Tecnologie Biologiche, Chimiche e Farmaceutiche, Università di Palermo, Viale \\ delle Scienze, I-9000 Palermo, Italy.
}

\begin{abstract}
Potato is a starchy, tuberous crop from the perennial Solanum tuberosum having high nutritional values. This paper is the first analytical approach to quantify $\mathrm{Pt}$ and $\mathrm{Rh}$ in vegetal food. In this study a total of 38 different potatoes samples produced in Europe and one in Australia were investigated. Determinations of $\mathrm{Pt}$ and $\mathrm{Rh}$ in potatoes samples were carried out by Differential Pulse Voltammetry (DPV/a) for platinum and by Adsorptive Stripping Voltammetry (AdSV) for Rh using standard addition procedure. Because no certified reference potatoes containing platinum and rhodium are available, we used addition standard method. The quantification limits for Pt and $\mathrm{Rh}$ are 0.007 and $0.0008 \mu \mathrm{g} \mathrm{Kg}{ }^{-1}$ respectively. Considering all the potatoes samples, concentrations of $\mathrm{Pt}$ and $\mathrm{Rh}$ vary in the ranges from 0.007 to $109 \mu \mathrm{g} \mathrm{Kg}^{-1}$ (sample $\mathrm{n}^{\circ} 6$ potatoes grown in Sicily) and from 0.0008 to $0.030 \mu \mathrm{g} \mathrm{Kg}^{-1}$ (sample ${ }^{\circ} 23$ of potatoes grown in Emilia Romagna) respectively. For both metals, in many cases the concentrations fall near the quantification limit. In all the samples, platinum is always more abundant than rhodium and their ratio meanly is 14500 , which is much greater than that of the earth's crust (about 100).
\end{abstract}

Keywords: Potatoes; Platinum; Rhodium; Voltammetry

\section{Introduction}

In most economically and socially evolved areas, the anthropic activity which appreciably has an effect on the environmental matrices quality is road transports [1,2]. Although, in latest years, traditional pollutant (NO, $\mathrm{CO}$, hydrocarbons, lead, etc.) emissions decreased appreciably, the concentrations in the atmosphere of metals $(\mathrm{Pt}, \mathrm{Pd}, \mathrm{Rh}, \mathrm{Ru}$ and $\mathrm{Ir})$, are increasing, in fact, these elements, known as Platinum Group Elements (PGEs), are used in catalysts to reduce pollutants in the exhaust system.

Platinum group metals are principally emitted from vehicles in elemental form or as oxides. Because the low size of particulate in emitted gasses [3] and the several reactions which PGEs undergo, considerable amounts of these elements can be transformed into bioavailable compounds (chloro or organic complexes) [4]. Also Pt complexes are used as anticancer drug with high efficacy against solid tumors, particularly testicular and ovarian cancer [5-7], consequently another source of this contaminant could be hospital incinerators.

Soil is most susceptible environmental matrix to PGEs contamination [8,9]. Anthropogenic activity has caused an increase in PGE concentration in the soil, especially in areas close to roads, as proven by a number of studies [10,11]. Researches comparing the average concentration of $\mathrm{Pt}$ in different types of soil samples have shown that Pt concentration amounts to $0.14 \mu \mathrm{g} / \mathrm{kg}$ in intact soil (i.e., without human intervention) and $1.12 \mu \mathrm{g} / \mathrm{kg}$ in agricultural soil, while it reaches $20.9 \mu \mathrm{g} / \mathrm{kg}$ in soil specimens collected from areas adjacent to roads [12].

Few quantifications [13] of PGEs concentrations have ever been carried out in food from the time when these metals were used in car mufflers and as anticancer drugs and no information are available on platinum and rhodium concentrations in potatoes. 
Potato is a starchy, tuberous crop from the perennial Solanum tuberosum, introduced by the Spanish to Europe in the second half of the 16th century. Potatoes have high nutritional values, such as a high protein content (containing 18 essential amino acids, including various amino acids that the human body cannot synthesize), vitamins (including vitamin $C$ and others that are useful for the human body), abundant dietary fiber and little fat.

This paper is the first analytical approach to quantify Pt and Rh in vegetal food. In this study a total of 38 different potatoes samples produced in Europe and one in Australia were investigated.

Recently, a research group [14] investigated potentially toxic metals ( $\mathrm{As}, \mathrm{Cd}, \mathrm{Cr}, \mathrm{Cu}, \mathrm{Hg}, \mathrm{Pb}, \mathrm{Se}$, Zn), excluding PGEs, in agricultural samples (Solanum tuberosum L. tubers) in a zinc smelting area of northwestern Guizhou Province (China). The health risks linked to potato consumption, respect to potentially toxic metal are a very important subject, because, today they are a primary food in many parts of the world.

The potatoes quality control requires the development of reliable analytical methods to measure very low hazardous contaminants concentrations in food and environmental matrices, as well to estimate their background concentrations. In particular, the main intention of this work was to develop a reliable method for the quantification of $\mathrm{Pt}$ and $\mathrm{Rh}$ in complexes matrices, as potatoes, because they cannot be readily measured using conventional techniques employed in most laboratories, in particular, the ICP techniques due to matrix and spectra interferences. Moreover, a direct determination of platinum and rhodium at ultra trace levels by ICP-MS is difficult, due to the separation of this metal from the matrix and to interfering signals which cannot be eliminated [15-18].

In most cases, voltammetric methods are used for individual and simultaneous determination of metals and chemical compounds when their concentrations are very low (under ppb). Numerous applications of voltammetry are reported in literature [19-21] but to the best of our knowledge, there are no information on the determination of ultra traces of $\mathrm{Pt}$ and $\mathrm{Rh}$ [22-25] in a complex matrix as potatoes. In this research, the Adsorptive Stripping Voltammetry (AdSV) and the Differential Pulsed Voltammetry (DPV) were used to measure the concentrations of Rh and Pt in the samples.

\section{Materials and methods}

\subsection{Instrumentation}

Instrumentation, laboratory apparatus, reagents and procedures used were described in previous papers $[9,26,27]$, however a brief summary is reported. The voltammetric instrumentation is constituted of a Polarograph Amel Model 433-A with a glass cell including an hanging mercury drop electrode (HMDE) (working electrode), a glassy carbon electrode (auxiliary) and an $\mathrm{Ag} / \mathrm{AgCl} / \mathrm{KCl}$ (sat) (reference electrode).

\subsection{Reagents}

The reagents used during this research were analytical grade (Carlo Erba, Milano, Italy) and all solutions were prepared in Milli-Q water. Platinum and Rhodium standard solutions $\left(1000 \mu \mathrm{g} \mathrm{mL}{ }^{-1}\right)$ were purchased from Fluka (Milano, Italy). The diluted solutions were prepared daily. $\mathrm{HNO}_{3}(65 \%)$ and $\mathrm{HCl}(37 \%)$ were analytical grade (Suprapur Carlo Erba, Milano, Italy). Hydrazine sulfate $\left(\mathrm{N}_{2} \mathrm{H}_{6} \mathrm{SO}_{4}\right)$ and formaldehyde $(\mathrm{HCHO})$ solutions were prepared daily from analytical grade reagents (Carlo Erba, Milano, Italy).

\subsection{Quality assurance}

All the materials used during the analysis were cleaned before use by rinsing three times with $\mathrm{HNO}_{3}(3 \%)$ and three times with Milli Q water. To avoid sample contaminations, different glassware and pipettes were used for standards and for solutions obtained from samples. The procedural blanks were routinely analyzed every six samples. Since certificate potatoes for the investigates platinum and rhodium are not available, all the analytical procedures were checked for accuracy by analyzing enriched samples prepared by us. The average recoveries of added analytes ranged from 
$80 \%$ to $95 \%$. The relative standard deviations on the metals measurements of recovery are about $15 \%$.

The detection (LOD) and quantification (LOQ) limits of the method, as in other researches $[26,27]$, were calculated as the three and tenfold standard deviation of concentrations found in 10 procedural blanks respectively, which were prepared in the same way as the potatoes samples.

\subsection{Samples}

The 38 analyzed samples had different geographical origins: Italy, Europe, Australia. Some of the samples are obtained from local farmers while others have been found on the market. In particular, 21 samples were potatoes from different parts of Sicily, 14 samples from northern Italy, 2 from France and one from Australia.

About 5-6 tubers of any type of sample were washed first with tap water and successively with Milli Q water. The periderm was peeled immediately before analysis. Each tuber was cut into several about similar little pieces using a ceramic knife. To obtain a representative sample, the tuber fragments were ground by a blender with a glass beaker and stainless steel blades.

\subsection{Mineralization procedure}

Two-3 g of sample finely ground, dried for $24 \mathrm{~h}$ at $105^{\circ} \mathrm{C}$, were ashed in a muffle at $600^{\circ} \mathrm{C}(5 \mathrm{~h})$. After cooling, the ashes were digested in $5 \mathrm{~mL}$ of concentrated $\mathrm{HCl}$ and filtered on $0,45 \mu \mathrm{m}$ filters. After treatment was completed, the clear, colorless solution was transferred into a volumetric flask and brought to volume with Milli-Q water. The water content was determined by weight loss and was used to correlate all the results with dry weight.

\subsection{Analytical methods}

Determinations of $\mathrm{Pt}$ and $\mathrm{Rh}$ in potatoes samples were carried out by Differential Pulse Voltammetry (DPV/a) for platinum and by Adsorptive Stripping Voltammetry (AdSV) for Rh using standard addition procedure.

The solutions containing the complexes chloride of platinum $\left(\mathrm{H}_{2} \mathrm{PtCl}_{4}, \mathrm{PtCl}_{4}{ }^{2-}\right)$ and rhodium $\left(\mathrm{RhCl}_{3}, \mathrm{RhCl}_{6}{ }^{3-}\right)$ were purged with analytical grade nitrogen $(99.998 \%)$ at the start of each measure for $300 \mathrm{~s}$ and a flow of gas was maintained over the solution during the measure to prevent oxygen interference. All experiments were performed at a temperature of $25^{\circ} \mathrm{C}$.

Pt determinations were carried out in aqueous $\mathrm{H}_{2} \mathrm{SO}_{4} 1 \mathrm{M}$ as supporting electrolyte, in the presence of $1.2 \mathrm{mM}$ hydrazine sulphate and $0.6 \mathrm{mM}$ formaldehyde. Formaldehyde and hydrazine condense in situ to produce the corresponding hydrazone, which forms a complex with Pt. Subsequently, a potential varying from - 0.3 to $-1.0 \mathrm{~V}$, in the differential pulse mode, was applied to the working electrode, and the catalytic current of the hydrogen formation was measured at - $0.85 \mathrm{~V}$ (versus $\mathrm{Ag} / \mathrm{AgCl}$ ); its intensity being proportional to platinum concentration [28]. The catalytic effect of Pt makes this determination extremely sensitive.

Rhodium quantifications were carried out by Adsorptive Stripping Voltammetry. This technique is known to give an incomparable sensitivity for several trace metals at a mercury electrode (film or drop); it involves complexation of metals with definite ligands and adsorption of the resulting complex on the mercury surface. The adsorbed complex is electrochemically removed by scanning the electrode potential, usually in a reductive direction. Since this is a surface technique, it is suitable for determining ultra-trace levels of metals in solutions.

In $\mathrm{HCl}(0.42 \mathrm{M})$ and $\mathrm{HCHO}(0.02 \mathrm{M})$ solution, a complex rhodium formaldehyde is adsorbed on a hanging mercury electrode at $-0.7 \mathrm{~V}$. The potential of the working electrode was then changed from - 0.9 to $-1.2 \mathrm{~V}$, obtaining a peak at $-1.1 \mathrm{~V}$ due to hydrogen reduction, catalyzed by rhodium complex. The catalytic effect of Rh explains the great sensitivity of the employed method.

The instrumental parameters are shown in Tables 1 and 2. The voltammogram of backgrounds were obtained before sample analysis by using the same experimental conditions of the samples. Voltammetric curves for the two analytes are shown in Figure 1. For both metals, quantitative 
measurements were performed using the standard addition procedure. Calibration graphs were built using data from measurements and evaluated by the least-squares linear regression method. Under the developed conditions, a very good linear correlation was obtained between the monitored voltammetric peak current and metals concentrations.

Table 1 Operating parameters for the voltammetric analysis (Differential Pulse Voltammetry and Adsorptive Stripping Voltammetry) of the solutions obtained from the ashes of potatoes samples.

\begin{tabular}{|c|c|c|c|}
\hline Analytes & Tecniques & Electrolytes & Reagent \\
\hline $\mathrm{Pt}$ & $\mathrm{DPV} / \mathrm{a}$ & $\mathrm{H} 2 \mathrm{SO} 41 \mathrm{M}$ & $\begin{array}{c}{[\mathrm{N} 2 \mathrm{H} 4 \mathrm{SO} 4]=} \\
=1.2 \mathrm{mmol} \mathrm{L}-1,[\mathrm{H} 2 \mathrm{CO}]=0.6 \\
\text { mmol L-1 }\end{array}$ \\
\hline $\mathrm{Rh}$ & DPSAV & $\mathrm{HCl} 0.42 \mathrm{M}$ & {$[\mathrm{H} 2 \mathrm{CO}]=0.02 \mathrm{~mol} \mathrm{~L}-1$} \\
\hline
\end{tabular}

Table 2 Operating parameters for the Differential Pulse Voltammetry and Adsorptive Stripping Voltammetry analysis of the solutions obtained from the potatoes samples.

\begin{tabular}{|c|c|c|}
\hline Parameter & $\mathrm{Pt}$ & Rh \\
\hline Initial potential $(\mathrm{mV})$ & -300 & -900 \\
\hline Final potential $(\mathrm{mV})$ & -1000 & -1200 \\
\hline Current range & Automatic & Automatic \\
\hline Potential scan rate $(\mathrm{mV} \mathrm{s}-1)$ & 50 & 10 \\
\hline Potential of deposition $(\mathrm{mV})$ & - & -700 \\
\hline Cycle ${ }^{\circ}$ & 1 & 1 \\
\hline Deposition time (s) & - & 30 \\
\hline Stirring rate (r.p.m.) & 300 & 300 \\
\hline Size of the drop (a.u.) & 60 & 60 \\
\hline Delay time before potential sweep (s) & 10 & 10 \\
\hline Working electrode & \multicolumn{2}{|c|}{ Hanging mercury drop electrode } \\
\hline Auxiliary electrode & \multicolumn{2}{|c|}{ Glassy carbon } \\
\hline Reference electrode & \multicolumn{2}{|c|}{$\mathrm{Ag} / \mathrm{AgCl} / \mathrm{KCl}$ (sat) } \\
\hline Flowing gas & \multicolumn{2}{|c|}{ Nitrogen $(99.998 \%)$} \\
\hline
\end{tabular}
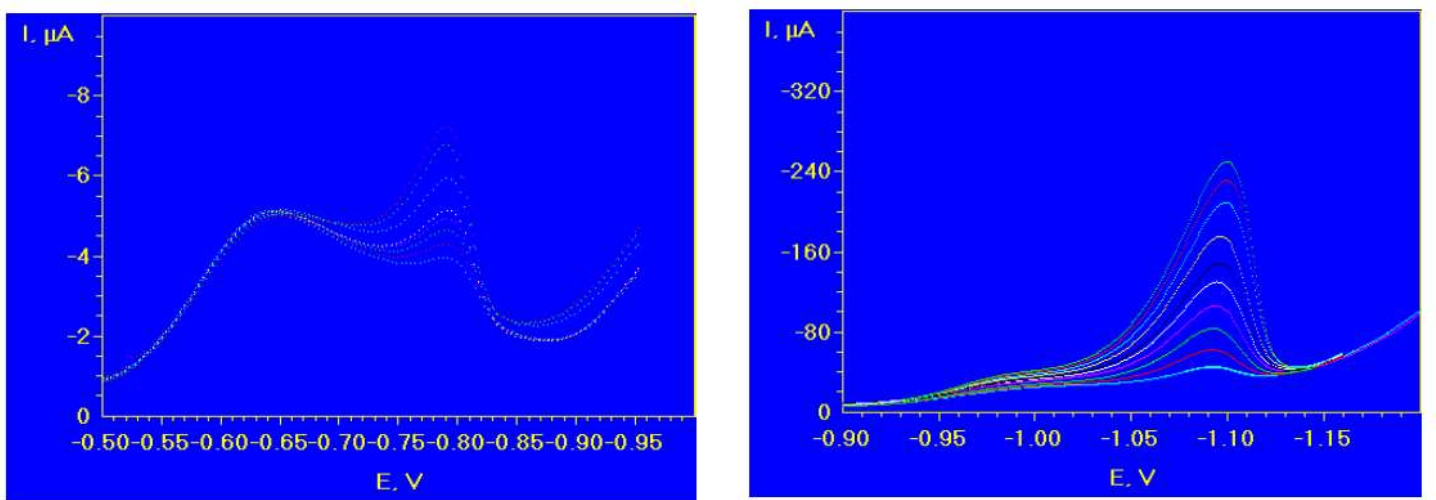

Figure. 1. Voltammetric curves for platinum and rhodium.

\section{Results and discussion}

The narrow range of $\mathrm{H}_{2} \mathrm{O}$ (from 72 to $83 \%$ ) found in the samples indicates, for this parameter, homogeneous chemical characteristics.

Because no certified reference potatoes containing platinum and rhodium are available, in this study, we used addition standard method. This method was used to validate the analytical methods because sample matrix and possible interferences could also contribute to the analytical signal, a situation known as the matrix effect, thus making it impossible to compare the analytical signal (in our case current) between sample and standard using the traditional calibration curve approach. Using the intercept (negative) on the curve, the employed volumes of solutions and the quantity of samples, we have calculated the concentrations of $\mathrm{Pt}$ or Rh in the different potatoes samples. Calibration graphs were built using data from measurements and evaluated by the least squares 
linear regression method. Under the optimum conditions a very good linear correlations $\left(\mathrm{R}^{2}=\right.$ 0.991-0.999 for platinum and 0.994-0.999 for rhodium) were obtained between the monitored voltammetric peak current and metal concentrations. The calibration curves, of which two (for platinum and rhodium) shown by way of example in Figure 2, indicate that the methods for the two metals are linear already starting from concentrations very close to the limits of quantification.

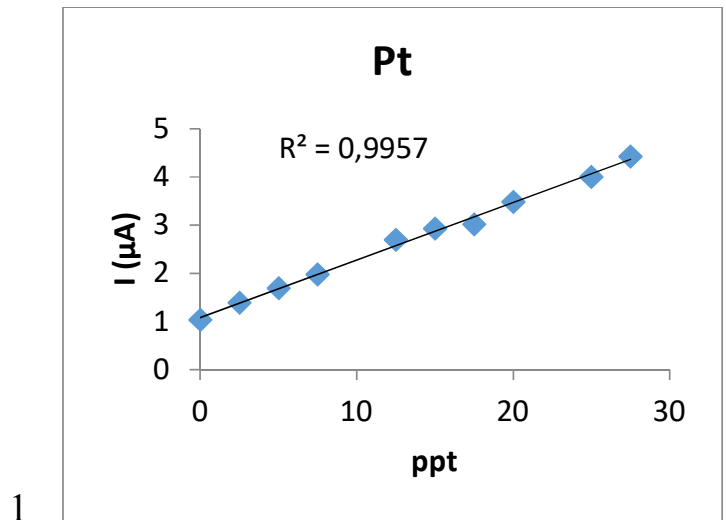

2 Figure. 2a. Voltammetric curves for platinum



4 Figure. 2b. Voltammetric curves for rhodium.

5

6

The precision of the electrochemically developed method, in terms of relative standard deviation (R.S.D. \%) for Pt and Rh, ranged from 0.5 to $25 \%$ and from 0.9 to $24 \%$ respectively. Relative Standard Deviations are very high for those samples in which analyte concentrations are close to quantification limits.

The quantification limits for Pt and Rh calculated for the analyzed solutions obtained from the mineralization of the samples (in the voltammetric cell) are 13 and $1.6 \mathrm{ng} \mathrm{L}^{-1}$ respectively, while, considering the samples weight, the volume of analyzed solutions and the dilutions the quantification limits for $\mathrm{Pt}$ and $\mathrm{Rh}$ are 0.007 and $0.0008 \mu \mathrm{g} \mathrm{Kg}{ }^{-1}$ respectively.

The concentrations of rhodium and platinum, obtained for the 38 analyzed potatoes samples are shown in Table 3 and Figure 2 and are referred to samples as such and not dried, exactly as they are consumed.

The concentrations, reported as mean of three independent analyses, are corrected for blanks. Considering all the potatoes samples, concentrations of $\mathrm{Pt}$ and $\mathrm{Rh}$ vary in the ranges from 0.007 to $109 \mu \mathrm{g} \mathrm{Kg}{ }^{-1}$ (sample $\mathrm{n}^{\circ} 6$ potatoes grown in Sicily) and from 0.0008 to $0.030 \mu \mathrm{g} \mathrm{Kg}^{-1}$ (sample ${ }^{\circ} 23$ of potatoes grown in Emilia Romagna) respectively. For both metals, in many cases the concentrations fall near the quantification limit. In all the samples, platinum is always more abundant than rhodium and their ratio meanly is 14500 , which is much greater than that of the earth's crust (about 100).

The highest platinum concentrations were found in two samples cultivated in Sicily in the province of Syracuse, which is in a highly industrialized area due to the presence of refineries and other chemical industries.

Table 3 - Platinum and rhodium concentrations in potatoes samples

\begin{tabular}{cccccc}
\hline Sample & Origin & $\begin{array}{c}\mathbf{P t} \\
(\mu \mathrm{g} / \mathbf{K g})\end{array}$ & $\begin{array}{c}\text { R.S.D. } \% \\
\mathbf{R h}\end{array}$ & $\begin{array}{c}\text { R.S.D. } \% \\
(\mu \mathrm{g} / \mathbf{K g})\end{array}$ \\
\hline 1 & 16 & 2.2 & 0.015 & 5.4 \\
2 & Italy - Sicily & 8.9 & 6.5 & 0.016 & 6.5 \\
3 & Italy - Sicily & 56 & 2.4 & 0.0008 & 11 \\
4 & Italy - Sicily & 6.7 & 6.1 & 0.0086 & 4.2 \\
\hline
\end{tabular}




\begin{tabular}{|c|c|c|c|c|c|}
\hline 5 & Italy - Sicily & 65 & 1.0 & 0.0008 & 10 \\
\hline 6 & Italy - Sicily & 109 & 0.5 & 0.0008 & 11 \\
\hline 7 & Francia & 13 & 6.2 & 0.0008 & 20 \\
\hline 8 & Italy - Veneto & 69 & 4.0 & 0.0008 & 12 \\
\hline 9 & Italy - Lazio & 20 & 3.5 & 0.0008 & 9.9 \\
\hline 10 & Italy - Marche & 12 & 5.2 & 0.0008 & 16 \\
\hline 11 & Italy - Emilia & 12 & 4.7 & 0.0008 & 4.9 \\
\hline 12 & Italy - Emilia & 17 & 2.3 & 0.0008 & 14 \\
\hline 13 & Italy - Sicily & 23 & 2.4 & 0.0008 & 13 \\
\hline 14 & Francia & 21 & 1.0 & 0.0008 & 13 \\
\hline 15 & Italy- Umbria & 1.3 & 5.6 & 0.0008 & 5.6 \\
\hline 16 & Belgio & 0.007 & 8.0 & 0.017 & 8.0 \\
\hline 17 & Italy - Campania & 0.007 & 11 & 0.0008 & 21 \\
\hline 18 & Italy - Puglia & 0.007 & 10 & 0.0008 & 25 \\
\hline 19 & Australia & 0.007 & 12 & 0.0008 & 12 \\
\hline 20 & Italy - Abruzzo & 0.007 & 16 & 0.0008 & 15 \\
\hline 21 & Italy - Sicily & 0.007 & 12 & 0.0008 & 16 \\
\hline 22 & Italy - Sicily & 0.21 & 3.2 & 0.0008 & 3.2 \\
\hline 23 & Emilia Romagna & 0.007 & 12 & 0.0303 & 6.1 \\
\hline 24 & Italy - Sicily & 0.007 & 13 & 0.0085 & 2.4 \\
\hline 25 & Italy - Sicily & 0.007 & 11 & 0.0008 & 25 \\
\hline 26 & Italy - Sicily & 0.007 & 18 & 0.0008 & 22 \\
\hline 27 & Italy - Puglia & 0.288 & 12 & 0.0087 & 11 \\
\hline 28 & Italy - Abruzzo & 0.233 & 15 & 0.0008 & 24 \\
\hline 29 & Italy - Sicily & 0.326 & 15 & 0.0008 & 16 \\
\hline 30 & Italy - Sicily & 0.007 & 10 & 0.0087 & 10 \\
\hline 31 & Italy - Sicily & 0.007 & 17 & 0.0008 & 21 \\
\hline 32 & Italy - Sicily & 0.007 & 14 & 0.0008 & 22 \\
\hline 33 & Italy - Sicily & 0.007 & 15 & 0.015 & 0.88 \\
\hline 34 & Italy - Sicily & 0.007 & 16 & 0.0008 & 24 \\
\hline 35 & Italy - Sicily & 0.007 & 18 & 0.016 & 7.6 \\
\hline 36 & Italy - Sicily & 0.007 & 25 & 0.016 & 7.2 \\
\hline 37 & Italy - Campania & 0.16 & 14 & 0.0008 & 14 \\
\hline 38 & Italy - Sicily & 23 & 1.2 & 0.0008 & 33 \\
\hline
\end{tabular}




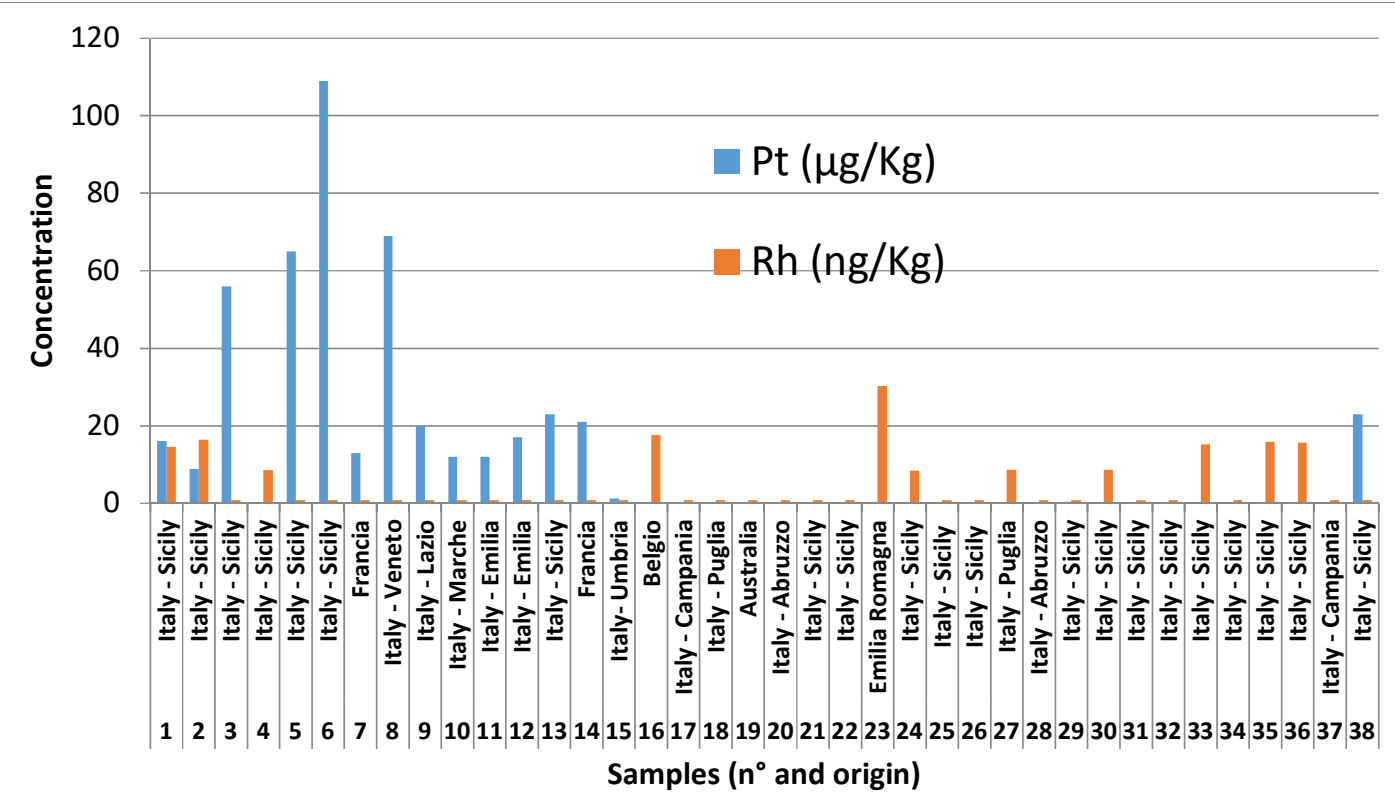

Figure 2 Platinum and rhodium concentrations in potatoes samples.

We tried to treat the results from the statistical point of view but we realized that there is no correlation between the different samples nor between the platinum data between them nor between those of the rhodium and even less between those of the two metals.

A comparison of the concentrations reported by us with those of literature is impossible due to the lack of data on the two analytes in the same matrix. For an evaluation, in table 4 we show the platinum and rhodium concentrations determined by several researchers [29] in some plant and fungal species sampled along roads and motorways. In Nerium oleander leaves, $\mathrm{Pt}$ and $\mathrm{Rh}$ concentrations were found by us in the ranges $0.33-25$ and $0.40-4.6 \mu \mathrm{g} \mathrm{kg}^{-1}$, respectively [26] (Table 4). These concentrations for platinum are of the same order of abundance than that observed in potatoes samples while Rh levels resulted lower.

Table 4 Platinum and rhodium concentrations in environmental matrices [29].

\begin{tabular}{cccc}
\hline Place & $\mathrm{Pt}(\mu \mathrm{g} / \mathrm{Kg})$ & $\mathbf{R h}(\mu \mathrm{g} / \mathrm{Kg})$ & Sample \\
\hline Stuttgart & 2.9 & - & roadside grass (1993) \\
Gent (Belgio) & 4.6 & - & roadside grass (0.2 meters) (1994) \\
& $1.4-1.7$ & - & roadside grass \\
Germania & 3.61 & 0.65 & roadside grass (1994) \\
& 10.6 & 1.54 & roadside grass (1997) \\
Sheffield & $\leq 0.03$ & $\leq 0.03$ & Area uncontaminated (1997) \\
Bialystok (Polonia) & $0.07-5.4$ & - & Bark \\
San Francisco & 8.63 & 0.65 & roadside grass (1 meters) \\
\hline
\end{tabular}

Regard the platinum, in samples of German plants, the concentrations are meanly of the same size compared to that found in the potatoes analyzed by us (meanly $12 \mu \mathrm{g} \mathrm{Kg}{ }^{-1}$ ), while the concentrations of rhodium in the German samples are undoubtedly higher.

A research on $\mathrm{Pt}$ concentration in the diet of Australian people was carried out about thirty years ago on market-basket samples [30]. Considering several food products from Sydney, the concentrations of Pt ranged from $8.1 \mu \mathrm{g} \mathrm{kg}-1$ (liver sample) to $0.13 \mu \mathrm{g} \mathrm{kg}^{-1}$ (full-cream milk). In particular, Pt contents were highest (meanly $5.8 \mu \mathrm{g} \mathrm{kg}^{-1}$ ) in eggs and offal followed, in decreasing order, by meat $\left(3.2 \mu \mathrm{g} \mathrm{kg}^{-1}\right)$, grain products $\left(3.2 \mu \mathrm{g} \mathrm{kg}^{-1}\right)$, fish $\left(1.8 \mu \mathrm{g} \mathrm{kg}^{-1}\right)$, fruit and vegetables $(0.82$ 
$\left.\mu \mathrm{g} \mathrm{kg}^{-1}\right)$ and products containing milk $\left(0.27 \mu \mathrm{g} \mathrm{kg}^{-1}\right)$ [30]. In Italian full cream milk, whole meal and bread, the rhodium concentrations are 1.68, 0.14 and $2.2 \mu \mathrm{g} \mathrm{kg}^{-1}$ respectively [27].

The enrichment factor (EF) [31,32] can be used to differentiate between the contaminants originating from anthropic activities and those from natural processes and to assess the degree of anthropogenic influence.

EF, evaluated relative to the background values [33], was used to establish which elements were relatively enriched in the different samples. Values of EF close to 1 pointing to a natural origin

while those $>10$ are considered to have a non-crustal source [31,32]. Further, EFs can also assist the determination of the degree of metal contamination. Five contamination categories are recognized on the basis of the enrichment factor (Table 5). In this study, considering $\mathrm{Pt}$, the enrichment factors ranged from 6.5.10-6 to 011, whereas for the rhodium, the values of EF are in the range $0.08-0.30$. The EFs calculated for all the samples indicate the natural origin of the two metals.

Table 5 Contamination categories based on EF values.

\begin{tabular}{cc}
\hline EF $<2$ & Deficiency to minimal enrichment \\
\hline EF 2-5 & Moderate enrichment \\
EF 5-20 & Significant enrichment \\
EF 20-40 & Very high enrichment \\
EF N 40 & Extremely high enrichment \\
\hline
\end{tabular}

Also in this paper, the degree of platinum and rhodium contamination in analyzed potatoes samples was characterized by geoaccumulation index (Igeo) [32]:

$$
\mathrm{I}_{\text {geo }}=\log _{2} \mathrm{C}_{\mathrm{me}}=1.5 \mathrm{~B}_{\mathrm{me}}
$$

where $\mathrm{C}_{\mathrm{me}}$ is the measured concentration of metal in the sample and $\mathrm{B}_{\mathrm{me}}$ is the geochemical background concentration in the hearth crust $\left(\mathrm{Pt}=10 \mu \mathrm{g} \mathrm{kg}^{-1} ; \mathrm{Rh}=0.1 \mu \mathrm{g} \mathrm{kg}^{-1}\right)$ [33]. The constant 1.5 allows us to consider natural fluctuations in the content of elements in the environment and to detect very small anthropogenic influences. Geoaccumulation index values for our data are shown in figure 3.

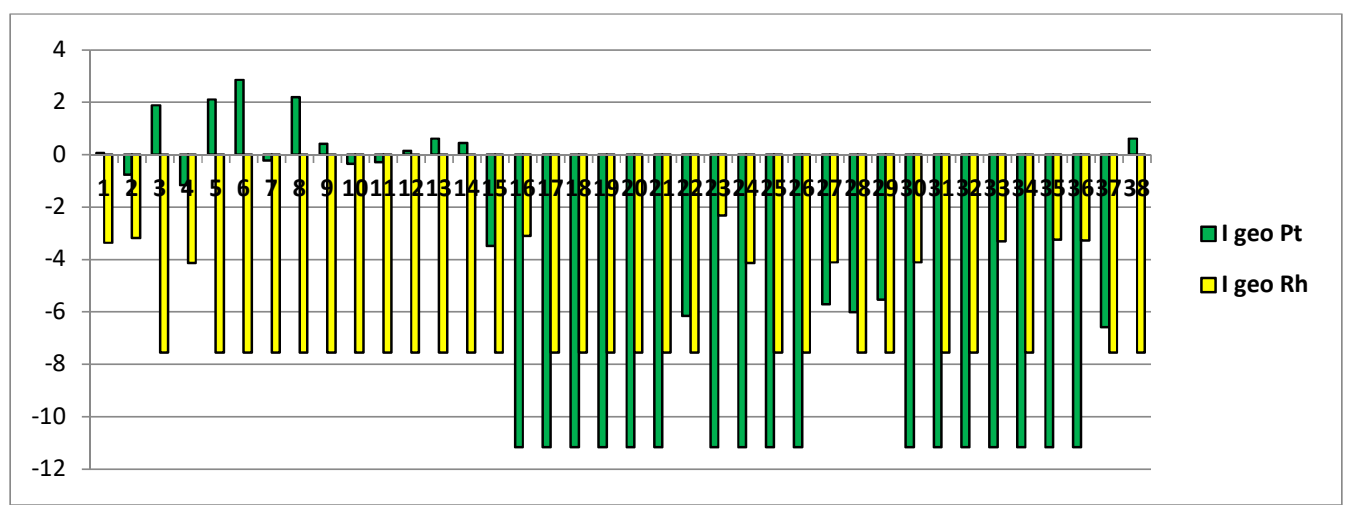

Figure 3 - Geoaccumulation index values

For geoaccumulation index, different classes are given in literature [32,33] (Table 6). Igeo ranged from - 11.2 to 2.9 with a mean of -0.27 , and from - 7.6 to -2.3 with a mean of -5.0 for platinum and rhodium respectively. From the data results that, for platinum, about $80 \%$ of the samples could be classified as practically uncontaminated, five moderately contaminated and three from moderately to heavily contaminated. The higher values of Igeo have been found in the potatoes samples $\left(\mathrm{n}^{\circ}\right.$ $3,5,6,8)$ grown in high-density industrial areas. 
For rhodium, in all the cases, the Igeo indicates practically uncontaminated potatoes samples.

Table 6 Geoaccumulation classes.

\begin{tabular}{ccc}
\hline Class & Index & Significance \\
\hline 0 & $<0$ & Practically uncontaminated \\
1 & $0-1$ & Uncontaminated to moderately contaminated \\
2 & $1-2$ & Moderately contaminated \\
3 & $2-3$ & Moderately to heavily contaminated \\
4 & $3-4$ & Heavily contaminated \\
5 & $4-5$ & Heavily to extremely contaminated \\
6 & 5 & Extremely contaminated \\
\hline
\end{tabular}

\subsection{Daily intake and health risk}

Concerning the health risks derived from the intakes of platinum and rhodium eating potatoes, the results derived from this research are compared with the available toxicological values [34].

The Food and Nutrition Board, in agreement with what established by the Institute of Medicine (FNB), for the $\mathrm{Pt}$, indicates a tolerable higher intake level of $0.3 \mu \mathrm{g}$ per day per $\mathrm{kg}$ of body weight [34] in the adult which corresponds to about $15 \mu \mathrm{g}$ per day for an individual weighing $50 \mathrm{~kg}$ [35]. European Medicines Agency guideline recommends the permitted daily exposition (PDE) for Pt (100 $\left.\mu \mathrm{g} \mathrm{d}^{-1}\right)$ and $\mathrm{Rh}\left(100 \mu \mathrm{g} \mathrm{d}^{-1}\right)$ residues in drug substances. In the present paper, the PDE is assumed as the maximum acceptable exposure to $\mathrm{Pt}$ and $\mathrm{Rh}$ on a chronic basis that is unlikely to produce any adverse health effects.

The daily intake depends both on the level of metals in the food and the amount consumed. Daily intake (DIM) of metals was calculated using the following equation:

$$
\mathrm{DIM}=\mathrm{C}_{\text {metal }} \cdot \mathrm{D}_{\text {food intake }}
$$

where $\mathrm{C}_{\text {metal }}$ and $\mathrm{D}_{\text {food intake }}$ represent the metal concentrations and daily intake of food respectively. Considering that Americans, on average, eat 35 kilograms of frozen potatoes, $19 \mathrm{~kg}$ of fresh potatoes, $8 \mathrm{~kg}$ of potato chips and $6 \mathrm{~kg}$ of dehydrated potato products per year we considered $100 \mathrm{~g} /$ person/day [36]. Consuming the considered daily amount of potatoes, this supply from 0.0007 to $11 \mu \mathrm{g}$ and from 0.00008 to $0.003 \mu \mathrm{g}$ of platinum and rhodium for person respectively. For comparison, the average diet of a Australian adult contains $1.4 \mu \mathrm{g}$ of platinum per day (adult male, $1.7 \mu \mathrm{g} \mathrm{Pt} \mathrm{day}{ }^{-1}$; adult female, $1.2 \mu \mathrm{g} \mathrm{Pt}$ day $^{-1}$ ), while in the United Kingdom the mean intake for rhodium is $0.2 \mu \mathrm{g} \mathrm{d}^{-1}$ [34].

In this study, the concentrations platinum and rhodium of great environmental and public interest in 38 different potatoes samples produced in several country were investigated. Only the voltammetric techniques were used to quantify the two heavy metals. The advantages about the employ of these analytical techniques are the high sensitivity that improved the limits of quantification levels for the two elements that are presents at low levels in some samples, simplicity, speed and low costs. Analyzed potatoes samples contain concentrations of Pt and Rh under the recommended levels by international organisms for other food. In our case, for potatoes consumers the estimated intake of $\mathrm{Pt}$ and $\mathrm{Rh}$ through the studied common food was lower than the reported values. It is not to ignore the fact that, in Italy and in other European countries, many people consume daily amounts of this vegetable several times greater than those we have assumed.

Acknowledgments: This work was performed thanks to the financial sources from the University of Palermo (FFR-D15-005906-1236, and PJ-Ric-ssffabr-2017).

\section{References}

1. [1] E. Helmers, N. Mergel, Platinum and rhodium in a polluted environment: studying the emissions of automobile catalysts with emphasis on the application of CSV rhodium analysis. Fresen J Anal Chem, 362, (1998) 522-8. 
2. [2] J. Schafer, H. Pulchet, Platinum group metals (PGM) emitted from automobile catalytic converters and their distribution in roadside soil, J. Geochem. Explor. 64, (1998) 307-314.

3. [3] R. Schlogl, G. Indlekofer, P. Oelhafen, Emission of micro particles from automotive sources-X-ray photoelectron-spectroscopy in environmental analysis, Angew. Chem. Int. Ed, 26, (1987) 309-319.

4. [4] S. Lustig, S. Zang, B. Michalke, P. Schramel,W. Beck, Transformation behavior of different platinum compounds in clay humic soil: speciation investigation, Sci. Total Environ, 188 (1996) 195-204.

5. [5] B. Rosenberg, L. Van Camp, E.B. Grimley, A.J. Thomson, The inhibition of growth or cell division in Escherichia coli by different ionic species of platinum(IV) complexes, J. Biol. Chem. 242 (1967) 1347-1352.

6. [6] L.R. Kelland, N.P. Farrell, Platinum-Based Drugs in Cancer Therapy, Humana Press ed., Totowa, New Jersey, 2000.

7. [7] S. Amatori, G. Ambrosi, A.E. Provenzano, M. Fanelli, M. Formica, V. Fusi, L. Giorgi, E. Macedi, M. Micheloni, P. Paoli, P. Rossi, PdII and PtII complexes with a thio-aza macrocycle ligand containing an intercalating fragment: structural and antitumor activity studies, J. Inorg. Biochem. 162 (2016) 154-161.

8. [8] S. Orecchio, D. Amorello, Platinum levels in urban soils from Palermo (Italy); analytical method using voltammetry, Microchem. J, 99 (2011) 283-288.

9. [9] S. Orecchio, D. Amorello, Voltammetric analysis of platinum in environmental matrices in platinum metals in the environment, in: Fathi Zerein, Clare L.S. Wiseman (Eds.), Springer 2015, 79-86.

10. [10] J. Schafer, H. Pulchet, Platinum group metals (PGM) emitted from automobile catalytic converters and their distribution in roadside soil, J. Geochem. Explor, 64 (1998) 307-314.

11. [11] Q.T. Liu, M.E. Diamond, S.E. Gingrich, J.M. Ondov, P. Maciejczyk, A.S. Gary, Accumulation

12. of metals, trace elements and semi volatile organic compounds on exterior windows surfaces in Baltimore, Environ. Pollut, 122 (2003) 51-61.

13. [12] H. Wichmann, G.A.K. Anquandah, C. Schmidt, D. Zachmann, A. Muefit Bahadir, Increase of platinum group element concentrations in soils and airborne dust in an urban area in Germany, Sci. Total Environ. 388 (2007) 121-127.

14. [13] D. Amorello, S. Barreca, E. Gulli, S. Orecchio, Platinum and Rhodium in wine samples by using voltammetric techniques, Microchemical J, 130, (2017), 229-235.

15. [14] Yishu Peng, Ruidong Yang, Tao Jin, Jun Chen, Jian Zhang, Risk assessment for potentially toxic metal(loid)s in potatoes in the indigenous zinc smelting area of northwestern Guizhou Province, China, Food and Chemical Toxicology, 120 (2018) 328-339.

16. [15] M. Krachler, A. Alimonti, F. Petrucci, K.J. Irgolic, S. Caroli, Analytical problem in the determination of platinum group metals in urine by quadruple and magnetic sector field inductively coupled plasma mass spectrometry, Anal. Chim. Acta 1 (1998) 363-369.

17. [16] S. Zimmermann, C.M. Menzel, Z. Berner, J.D. Eckhardt, D. Stüben, F. Alt, J. Messerschmidt, H. Taraschewski, B. Sures, Trace analysis of platinum in biological samples: a comparison between sector field ICP-MS and adsorptive cathodic stripping voltammetry following different digestion procedures, Anal. Chim. Acta, 439 (2001) 203-209.

18. [17] R. Vlasankova, V. Otruba, J. Bendl, M. Fisera, V. Kanicky, Preconcentration of platinum group metals on modified silica gel and their determination by inductively coupled plasma atomic emission spectrometry and inductively coupled plasma mass spectrometry in airborne particulates, Talanta, 48 (1999) 839-846.

19. [18] H.A. Panahi, H.S. Kalal, E. Moniri, M.N. Nezhati, M.T. Menderjani, S.R. Kelahrodi, F. Mahmoudi, Amberlite XAD-4 functionalized with m-phenylendiamine: synthesis, characterization and applications as extractant for preconcentration and determination of 
rhodium (III) in water samples by inductive couple plasma atomic emission spectroscopy (ICP-AES), Microchem. J, 93 (2009) 49-54.

20. [19] R. Piech, B. Baśa,W.W. Kubiaka, The cyclic renewable mercury film silver based electrode for determination of molybdenum(VI) traces using adsorptive stripping voltammetry, Talanta 76 (2008) 295-300.

21. [20] U. Celik, J. Oehlenschlager, Determination of zinc and copper in fish samples collected from Northeast Atlantic by DPSAV, Food Chem, 87 (2004) 343-347.

22. [21] A.I. Stoica, M. Peltea, G.E. Baiulescu, M. Ionica, Determination of cobalt in pharmaceutical products, J. Pharm. Biomed. Anal, 36 (2004) 653-656.

23. [22] C. Locatelli, Simultaneous square wave stripping voltammetric determination of platinum group metals (PGMs) and lead at trace and ultra trace concentration level, application to surface water, Anal. Chim. Acta 557 (2006) 70-77.

24. [23] D. Amorello, S. Orecchio, Micro determination of dithiocarbamates in pesticide formulations using voltammetry, Microchem. J. 110 (2013) 334-339.

25. [24] C. Leon, H. Emons, P. Ostapczuk, K. Hoppstock, Simultaneous ultra trace determination of platinum and rhodium by cathodic stripping voltammetry, Anal. Chim. Acta 356 (1997) 99-104.

26. [25] S. Orecchio, D. Amorello, C. Carollo, Voltammetric determination of platinum in perfusate and blood: preliminary data on pharmacokinetic study of arterial infusion with oxaliplatin, Microchem. J. 100 (2012) 72-76.

27. [26] S. Orecchio, D. Amorello, Platinum and rhodium associated with the leaves of Nerium oleander L.; analytical method using voltammetry; assessment of air quality in the Palermo (Italy) area, J. Hazard. Mater. 174 (2010) 720-727.

28. [27] S. Orecchio, D. Amorello, Platinum levels in urban soils from Palermo (Italy); Analytical method using voltammetry. Microchem. J. 99, (2011), 283-288.

29. [28] H.A. Panahi, H.S. Kalal, E. Moniri, M.N. Nezhati, M.T. Menderjani, S.R. Kelahrodi, F. Mahmoudi, Amberlite XAD-4 functionalized with m-phenylendiamine: synthesis, characterization and applications as extractant for preconcentration and determination of rhodium (III) in water samples by inductive couple plasma atomic emission spectroscopy (ICP-AES), Microchem. J. 93 (2009) 49-54.

30. [29] E. Helmers, N. Mergel, Platinum and rhodium in the polluted environment: studying the emissions of automobile catalysts with emphasis on the application of CSV rhodium analysis - Fresenius J Anal Chem. 362 (2002), 522-528.

31. [30] G.T. Vaughan, T.M. Florence, Platinum in the human diet, blood, hair and excreta, Sci. Total Environ. 111 (1992) 47-58.

32. [31] E. Helmers, M. Schwarzer, M. Schuster, Comparison of palladium and platinum in environmental matrices: palladium pollution by automobile emissions, Environ. Sci. Pollut. Res. 5 (1998) 44-50.

33. [32] R.F. Nolting, A. Ramkema, J.M. Everaarts, The geochemistry of $\mathrm{Cu}, \mathrm{Cd}, \mathrm{Zn}, \mathrm{Ni}$ and $\mathrm{Pb}$ in sediment cores from the continental slope of the banc d'Arguin (Mauritania), Cont. Shelf Res. 19 (1999) 665-691.

34. [33] N.N. Greenwood, A. Earnshaw, Chemistry of the Elements, Pergamon Press, 1985.

35. [34] European Medicines Agency Pre-authorization Evaluation of Medicines for Human Use, Doc. Ref. CPMP/SWP/QWP/4446/00 corr, 2007 (London).

36. [35] K. Hoppstock, B. Sures, Platinum group metals, in: E. Merian, M. Anke, M. Ihnat, M. Stoeppler (Eds.), Elements and Their Compounds in the Environment, Wiley-VCH, Weinheim 2004, 1047-1086.

37. [36] https://www.livescience.com/45838-potato-nutrition.html. 